\title{
The Hyperparasite, Urosporidium spisuli sp. n. (Haplosporea), and Its Effects on the Surf Clam Industry
}

\author{
Frank O. Perkins \\ Virginia Institute of Marine Science \\ D. E. Zwerner \\ Virginia Institute of Marine Science \\ Robert K. Dias \\ Virginia Institute of Marine Science
}

Follow this and additional works at: https://scholarworks.wm.edu/vimsarticles

Part of the Marine Biology Commons

\section{Recommended Citation}

Perkins, Frank O.; Zwerner, D. E.; and Dias, Robert K., The Hyperparasite, Urosporidium spisuli sp. n. (Haplosporea), and Its Effects on the Surf Clam Industry (1975). Journal of Parsitology, 61(5), 944-949. https://scholarworks.wm.edu/vimsarticles/1989 


\title{
THE HYPERPARASITE, UROSPORIDIUM SPISULI SP. N. (HAPLOSPOREA), AND ITS EFFECTS ON THE SURF CLAM INDUSTRY*
}

\author{
Frank O. Perkins, D. E. Zwerner, and Robert K. Dias \\ Virginia Institute of Marine Science, Gloucester Point, Virginia 23062
}

ABSTRACT: Surf clams (Spisula solidissima) from along the Virginia and North Carolina coasts are infected with an immature anisakid nematode worm which does not cause economic concern until infected with the protozoan hyperparasite, Urosporidium spisuli sp. n. When the protozoan sporulates the spores give the worm a brownish-black appearance, thus making it readily visible in clam tissues. Light and electron microscope studies of the spores reveal characteristics which differentiate the protozoan from other species of Urosporidium. All spores are killed after 5 to $30 \mathrm{~min}$ at $100 \mathrm{C}$; therefore, the consumer would not ingest live spores when eating commercially prepared clam meat.

Surf clams (Spisula solidissima) have become an important species in the United States seafood industry. In 1973 the exvessel or landing value of the surf clam industry was valued at $\$ 9.8 \mathrm{M}$ and the processed value reached a record level of about $\$ 38 \mathrm{M}$ (Anonymous, 1974). It was therefore of considerable economic concern when, in the last few years, dark brown worms were noted in the foot and adductor muscles of large numbers of $\mathrm{S}$. solidissima from Virginia waters (Fig. 1). Samples of clams from the Atlantic Ocean in the vicinities of Oregon Inlet, N. C., False Cape, Va., and the Chesapeake Light off the Virginia Capes were found to be $16 \%$ infected with nematodes containing spores of $U$. spisuli $(\mathrm{N}=894)$. Sightings of the brown worms resulted in clams being withheld from the commercial trade in Maryland.

Subsequent studies in this laboratory have revealed that the worms (1) were parasites of the clams prior to recognition of the commercial problem and (2) are immature anisakid nematodes similar to Paranisakiopsis pectinis (Cobb 1930) Mosgovoy 1951, not previously reported from S. solidissima. The present systematic position of the worm is uncertain, because mature individuals have not been found.

The worms were not previously noticed or reported by workers in the industry, probably because they are normally similar in color and density to the host tissues. We have determined that the nematodes become dark brown

Received for publication 13 March 1975.

* Contribution No. 692, Virginia Institute of Marine Science, Gloucester Point, Virginia 23062. when a haplosporidan hyperparasite, found in the pseudocoel, sporulates, forming large masses of golden brown spores contained in vermiform sporocysts (Fig. 2). The parasite has been determined to be a new species of Urosporidium.

Sections of $U$. spisuli and whole mounts of spores were prepared for electron microscopy using the techniques described by Perkins (1971).

\section{DESCRIPTION}

\section{Urosporidium spisuli sp. $\mathrm{n}$.}

(Figs. 2-5)

Host: An immature anisakid nematode similar to Paranisakiopsis pectinis (Cobb 1930) Mosgovoy 1951, which parasitizes the surf clam, Spisula solidissima.

Locality: Vicinity Chesapeake Light, off Capc Henry, Virginia, N. Atlantic Ocean.

Habitat: Pseudocoel.

Sporulation occurs in pseudocoel to yield unbranched and branched vermiform sporocysts up to $0.5 \mathrm{~mm}$ long. Living spores (volume delimited by wall) ovoid, range from 3.8 to $6.9 \mu \mathrm{m}$ by 3.0 to $5.9 \mu \mathrm{m}\left[\mathrm{N}=100 ; \hat{\mathrm{x}} \pm\left(\mathrm{S}_{\mathrm{z}}\right)\left(\mathrm{t}_{0.05}\right)=4.9 \pm\right.$ 0.05 and $4.4 \pm 0.04]$. Epispore cytoplasm extended centrifugally into 2 or 3 slender extensions about 7 to $14 \mu \mathrm{m}$ long. Each extension is membrane-limited and contains 1 to 3 tubes, each consisting of an electron-dense cortex surrounding a lumen. Sheets of striated material with periodicities of 15 to $17 \mathrm{~nm}$ are attached to the spore wall and extend throughout the epispore cytoplasm in a labyrinthuline complex. Anterior end of spore wall marked by a circular pore region which is occluded by a flap of wall material. No "spherule" or Golgi apparatus present in the spores. A 2- to 3- $\mu \mathrm{m}$-long bundle of fibers each measuring 16 to $20 \mathrm{~nm}$ in diameter is found in the spore cytoplasm. 


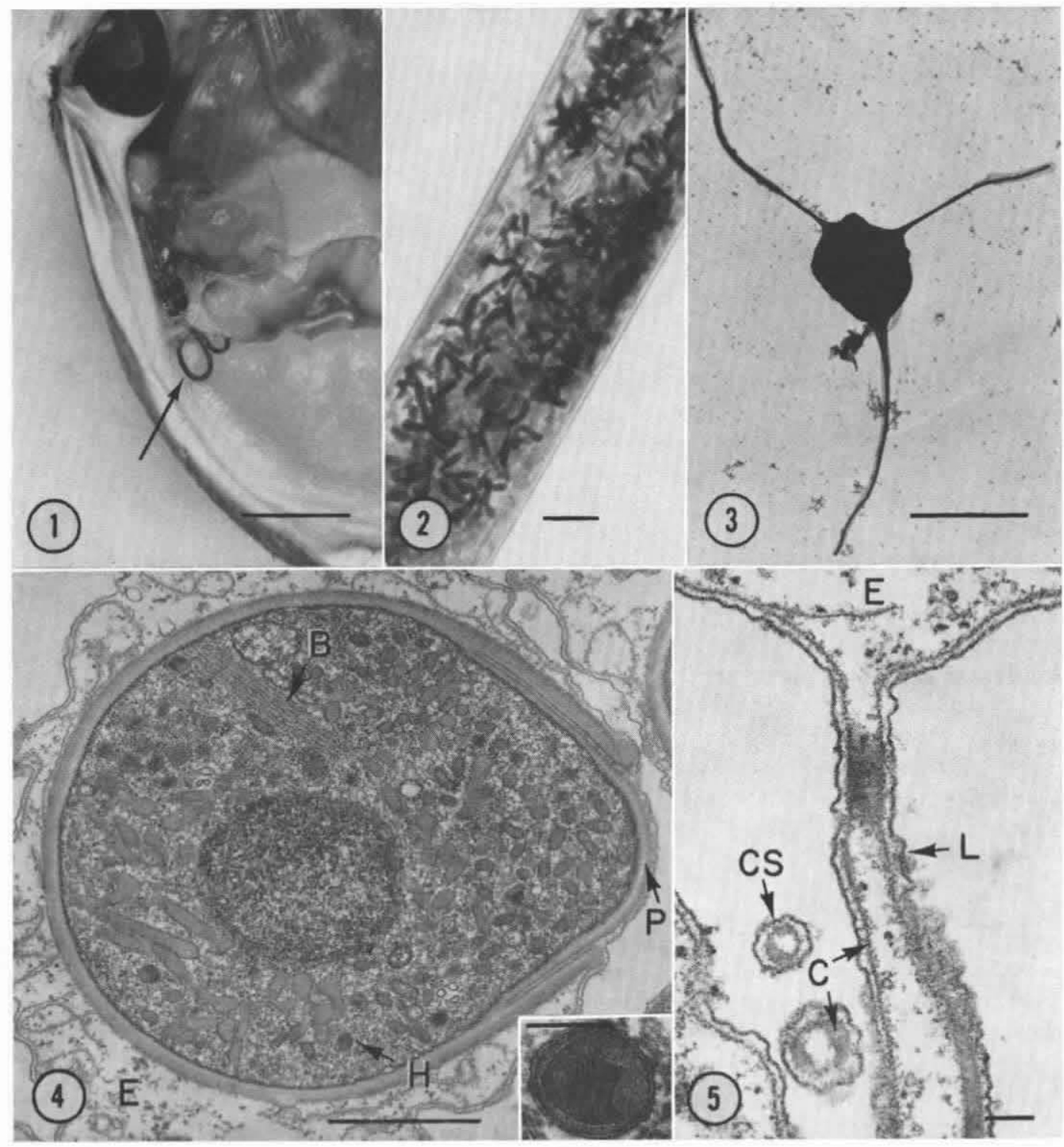

Figures 1-5. Urosporidium spisuli sp. n. parasitic in a nematode parasite of the surf clam, Spisula solidissima. 1. Clam showing hyperparasitized nematode (arrow) embedded between adductor and foot retractor muscles. Bar $=10 \mathrm{~mm}$. 2. Hyperparasitized nematode containing vermiform sporocysts of Urosporidium spisuli. Bar $=0.5 \mathrm{~mm}$. 3. Whole mount of $U$. spisuli spore showing three appendages. Bar $=5 \mu \mathrm{m}$. 4. Spore of $U$. spisuli showing pore region $(\mathrm{P})$, haplosporosome $(\mathrm{H})$, epispore cytoplasm (E), bundle of microtoubules (B). Bar $=1 \mu \mathrm{m}$. Inset: spore haplosporosome. Note delimiting unit membrane. Bar $=0.1 \mu \mathrm{m}$. 5. Appendages of spore showing electron-dense core (C) in longitudinal (L) and cross-sectional orientation (CS). Epispore cytoplasm (E). Bar $=0.1 \mu \mathrm{m}$.

\section{Remarks}

Although it is uncertain how spores are delimited, the sporulation sequence is otherwise essentially the same as previously described (Perkins, 1971; Ormières et al., 1973).
Spores are uninucleate and have a cup-shaped ovoid wall consisting of two primary layers, the inner one being thinner and more electrondense than the outer (Fig. 4). At the anterior end there is a circular pore delimited by a ridge 
which consists of localized thickening of the wall. Within the ridge the wall is thinner than the main spore case, thus forming a circular depression or pore region as seen in other species of Urosporidium (Perkins, 1971; Ormières et al., 1973). The thin portion of wall material extends under the main spore wall and is attached to the overlying wall except in one area so that when the spore protoplast emerges the thin wall is turned outward through the pore.

The spore cytoplasm contains membranelimited, electron-dense bodies, termed haplosporosomes (Perkins, 1971). They are spheroidal or oblate inclusions 85 to $149 \mathrm{~nm}$ along shortest axis $(\mathrm{N}=50)$ with a bipartite substructure (Fig. 4). An inner electron-light zone separates the two electron-dense portions. Haplosporosomes have been found in all but one species of Minchinia and one species of Haplosporidium thus far examined by electron microscopy (Perkins, 1968, 1969, 1971, 1975; Ormières et al., 1973) and appear to be found only in the Haplosporea. The function of the organelles is unknown.

Membrane-bound vesicles and cisternae containing granular material of lower electron density than the haplosporosomes are also found scattered throughout the cytoplasm (Fig. 4) rather than being organized into an anastomosing complex of cisternae as in $U$. crescens and $U$. jiroveci. The cisternae of $U$. spisuli range from spherical to tubular (branched or straight) units with cross-sectional diameters of 80 to $230 \mathrm{~nm}(\mathrm{~N}=20)$. Tubular units may be as long as $2.5 \mu \mathrm{m}$.

Haplosporosomes appear to be formed within or from the cisternae as evidenced by intermediate stages. The sequence is not in reverse order as seen by the increase in numbers of haplosporosomes and decrease in the cisternae as spores mature. U. crescens appears to utilize the same morphogenetic sequence (Perkins, 1971).

Other organelles of the spore consist of a single nucleus and one or two tubulovesicular mitochondria. The ground cytoplasm contains a small number of membrane-free ribosomes and a limited amount of endoplasmic reticulum. One or two Golgi apparatuses are present in immature spores, but have not been seen in mature ones. Mature and immature spores contain a 2.0- to $3.0-\mu \mathrm{m}$-long bundle of microfibers, each microfiber being 16 to $20 \mathrm{~nm}$ in diameter and extending about $1 / 3$ to $3 / 4$ of the length of the bundle (Fig. 4). Cross sections of the microfibers reveal a hexagonal packing involving up to about 300 microfibers.

Surrounding the developing spore and outside the wall is a layer of anucleate cytoplasm, the epispore cytoplasm. Extending from the layer are two or three rodlike, membranelimited appendages which reach a length of 7 to $14 \mu \mathrm{m}$ (Fig. 3). Each rod consists of one to three cores, each of which, in turn, consists of a tubular structure which has an electrondense cortex and electron-light center (Fig. 5). The cores arise from sheets of striated material with periodicities of 15 to $17 \mathrm{~nm}$. The sheets are attached to the spore wall and form a labyrinthine complex in the epispore cytoplasm.

\section{DISCUSSION}

U. spisuli is considered to be a member of the genus because: (1) the spore wall and sporoplasm closely resemble that of $U$. fuliginosum (Caullery and Mesnil, 1905), $U$. crescens (Perkins, 1971), and $U$. jiroveci (Ormières et al., 1973); and (2) epispore cytoplasm is extended into tapering structures reinforced by cytoplasmic fibrils as observed by Perkins (1971) and Ormières et al. (1973). Sporulation cell stages are consistent with those of other haplosporidans in which a sporont, then sporocyst, is formed.

$U$. spisuli is described as a new species, primarily because it is the first description of a species of Urosporidium parasitizing a nematode. The most similar species is $U$. pelseneeri (Caullery and Chappellier 1906) Dollfus 1925 found in the trematode Cercaria pectinata which parasitizes the clam Donax vittatus along the Atlantic coast of France. U. pelseneeri is the only other species of Urosporidium which normally forms two or three epispore extensions (Dollfus, 1925; Sprague, 1970). Extensions of $U$. pelseneeri are about 10 to $11 \mu \mathrm{m}$ (Dollfus, 1925) while those of $U$. spisuli are 7 to 14 $\mu \mathrm{m}$. Spore diameters are within the same range as U. spisuli. Caullery and Chappellier (1906) recorded the diameter as being 4.5 to $5 \mu \mathrm{m}$ and Dollfus (1925) recorded 5 to $5.5 \mu \mathrm{m}$. 
U. spisuli spore diameters are 3.0 to $5.9 \mu \mathrm{m}$. It is assumed that "diameter" means the shortest axis from outside to outside of spore wall in those cells which are oblate. All species the senior author has examined (U. crescens, U. spisuli, and Urosporidium sp. from trematodes in Paleomonetes pugio) are oblate to spherical, not exclusively spherical. All other authors have recorded only "diameters" even though micrographs or drawings of oblate spores are often presented, e.g., Ormières et al. (1973), Caullery and Mesnil (1905).

We consider $U$. spisuli to be a separate species from $U$. pelseneeri, because of host and geographical differences, and the wider range of spore "diameters" in the former. In the absence of a fine structure description of the latter species, further assessments cannot be made. This omission underlines the necessity for ultrastructural studies in elucidating species differences in the genus. A survey of the literature on the genus reveals that in most cases the only substantial reasons for creating a new species have been host and geographical differences. Lengths, and numbers of epispore extensions and spore diameters have shown considerable overlap from species to species. Size of sporocysts and degree of inflation of the basal portion of the epispore extensions are so highly variable as to be of doubtful value. Spore diameter is probably a valid taxonomic character; however, its limitations, as previously recorded, must be recognized. Measurements must be made from living cells rather than from fixed ones since fixation often causes a decrease in size particularly when followed by dehydration. Often it has not been stated whether living cells were measured (Caullery and Chappellier, 1906; Dollfus, 1925; Caullery and Mesnil, 1905; Howell, 1967). The axis measured was not stated for any of the species except the present. In considering all species one finds that spore diameters overlap markedly thus reducing the credibility of spore size as a taxonomic marker ( $U$. fuliginosum, Caullery and Mesnil, 1905: $5 \mu \mathrm{m}$; U. pelseneeri, Caullery and Chappellier, 1906; Dollfus, 1925: 4.5 to $5.5 \mu \mathrm{m}$; U. jiroveci, Ormières, Sprague, and Bartoli, 1973: 5.5 to $7 \mu \mathrm{m}, \overline{\mathrm{x}}=6.6 ; U$. constantae, Howell, 1967: 4 to $5 \mu \mathrm{m}$; U. crescens, DeTurk, 1940: 4.97 to $5.68 \mu \mathrm{m} ; U$. tauricum, Zaika and Dolgikh, 1963: 5.5 to
$7.5 \mu \mathrm{m})$. It would be useful if all spore sizes were presented giving ranges, means, and standard errors then reasonable judgments could be made.

In the future the greatest potential for elucidation of species differences within the genus will lie in descriptions of fine structure. For example, in the three species examined by electron microscopy it appears that epispore fibrils and ribbons may be useful in distinguishing species. Those of $U$. crescens (Perkins, 1971) and $U$. jiroveci (Ormières et al., 1973) are similar in appearance; however, measurements of periodicities cannot be compared because those of $U$. jiroveci were not published. Those of $U$. spisuli are clearly different from the other two species (compare figs. 12-14, Perkins, 1971, and figs. 16 and 17, Ormières et al., 1973, with Figs. 4 and 5 of the present work). It would be useful to examine the fine structure of all species of Urosporidium and in particular the epispore fibers and ribbons. Possibly stronger taxonomic distinctions will emerge from comparisons of this type.

The economic concern caused by sporulation of $U$. spisuli is the second example where sporulation of a hyperparasite has caused problems. As described by Perkins (1971), $U$. crescens infects the metacercaria of the trematode Carneophallus sp. which, in turn, infects the blue crab, Callinectes sapidus. When sporulation of $U$. crescens occurs, encysted, 0.3 to $1 \mathrm{~mm}$ diameter, metacercariae become dark brown or black causing the syndrome known as pepper crab disease which has resulted in crabs being withheld from the market as in the case of S, solidissima. In some regions the incidence of "pepper" crabs can be significant as evidenced by an unpublished 1967 to 1968 survey by Van Engle of the Virginia Institute of Marine Science where $53 \%$ of crabs around Wachapreague, Virginia, were found with black encysted metacercariae.

At present the life cycle of the nematode and U. spisuli are unknown; therefore, predictions as to when or where hyperparasitized worms will appear in clam meats cannot be offered. Even if the life cycle of the surf clam worm were known, the life cycle of $U$. spisuli would probably be in question, because it is unlikely that infections are transmitted from 
worm to worm. With the possible exception of Barrow's (1965) studies, no haplosporidan spores have been shown to infect individuals of the same species from which they were obtained (Pixell-Goodrich, 1915; Taylor, 1966). We have not been successful in attempts to infect oysters (Crassostrea virginica) with spores of Minchinia nelsoni and M. costalis, trematode metacercariae (Carneophallus sp.) with spores of Urosporidium crescens, and Panopeus herbstii with spores of Minchinia sp.

There appears to be no potential health hazard from ingesting commercially prepared meats of S. solidissima which contain U. spisuli, because all clams are cooked prior to eating and none are used in the half-shell or raw trade. Processing methods include deep fat frying or retorting clam meats in which temperatures range from approximately $132 \mathrm{C}$ for $8 \mathrm{~min}$ to $116 \mathrm{C}$ for $90 \mathrm{~min}$. All of the spores of $U$. spisuli appear to be killed after $5 \mathrm{~min}$ at $100 \mathrm{C}$ as determined by the eosin $\mathrm{Y}$ dye exclusion test for cell viability $(0.17 \%$ eosin $\mathrm{Y}$ in molluscan physiological saline equivalent to $35 \%$ seawater $)$. Evans' blue staining $(0.25 \%$ in estuarine water) (Crippen and Perrier, 1974 ) indicates that $30 \mathrm{~min}$ at $100 \mathrm{C}$ is required before all are killed. Parasitized nematodes removed from host tissues were unable to survive more than $24 \mathrm{hr}$ in molluscan physiological saline at $37 \mathrm{C}$ and were killed in vivo in a commercial processing step employing $132 \mathrm{C}$ for $8 \mathrm{~min}$. Even if the clams were eaten raw it is unlikely that there would be a health hazard from the protozoan. No Haplosporea resembling Urosporidium have been reported from vertebrates.

\section{ACKNOWLEDGMENTS}

We thank Dr. J. Ralph Lichtenfels of the Animal Parasitology Institute, USDA, Beltsville, Maryland, for assistance in identifying the nematode and Ms. Deborah DeBiasi, Ms. Sandra Jarvis, and Ms. Susan Fox for their technical assistance.

This study was partially supported by Sea Grant Contract Number 04-5-158-49, U. S. Dept. Commerce, NOAA.

\section{LITERATURE CITED}

AnONYmous. 1974. Fisheries of the United States, 1973. Statistics and Market News Division, U. S. Dept. Commerce, NOAA,
National Marine Fisheries Service. Current Fishery Statistics No. 6400.

Barrow, J. H., Jr. 1965. Observations on Minchinia pickfordae (Barrow 1961) found in snails of the Great Lakes region. Trans Am Microse Soc 84: $587-593$.

Caullery, M., and A. Chappellier. 1906. Anurosporidium pelseneeri, n.g. n. sp., haplosporidie infectant les sporocystes d'un trematode parasite de Donax trunculus L. C R Soc Biol, Paris 60: $325-328$.

-, AND F. MESNIL. 1905. Sur quelques nouvelles haplosporidies d'annélide. C R Soc Biol, Paris 58: 580-583.

Cruppen, R. W., and J. L. Perrier. 1974. The use of neutral red and Evans blue for livedead determinations of marine plankton. Stain Technol 49: 97-104.

DeTurk, W. E. 1940. The occurrence and development of a hyperparasite, Urosporidium crescens sp. nov. (Sporozoa, Haplosporidia) which infests the metacercariae of Spelotrema nicolli, parasitic in Callinectes sapidus. J Elisha Mitchell Sci Soc 56: 231-232.

Dollfus, R. PH. 1925. Liste critique des cercaires marines à queue sétigère signalées jusqu'à preśent. Trav Sta Zool Wimereux 9: 43-65.

Howell, M. 1967. The trematode, Bucephalus longicornutus (Manter, 1954), in the New Zealand mud-oyster, Ostrea lutaria. Trans R Soc N Z Zool 8: 221-237.

Ormik̀res, R., V. Sprague, and P. Bartoli. 1973. Light and electron microscope study of a new species of Urosporidium (Haplosporida), hyperparasite of trematode sporocysts in the clam Abra ovata. J Invertebr Pathol 21: 71-86.

Perkins, F. O. 1968. Fine structure of the oyster pathogen Minchinia nelsoni (Haplosporida, Haplosporidiidae). J Invertebr Pathol 10: $287-305$.

-1969. Electron microscope studies of sporulation in the oyster pathogen, Minchinia costalis (Sporozoa: Haplosporida). J Parasitol 55: 897-920.

- 1971. Sporulation in the trematode hyperparasite Urosporidium crescens DeTurk, 1940 (Haplosporida: Haplosporidiidae)-an electron miscroscope study. J Parasitol 57: 9-23.

- 1975. Fine structure of Minchinia sp. (Haplosporida) sporulation in the mud crab Panopeus herbstii. In G. Pauley (ed.), Diseases of Crustaceans. Marine Fish. Rev. U. S. Dept. Commerce, National Marine Fisheries Service 37: 46-60.

Pixell-Goodrich, H. L. M. 1915. Minchinia: a haplosporidian. Proc Zool Soc Lond 1915: 445-457.

Sprague, V. 1970. Some protozoan parasites and hyperparasites in marine bivalve molluses. P. 511-526, in S. F. Snieszko, (ed.), A Symposium on Diseases of Fishes and Shell- 
fishes. Spec Publ 5, Am Fish Soc, Washington, D. C.

TAYLOR, R. L. 1966. Haplosporidium tumefacientis sp. n., the etiologic agent of a disease of the California sea mussel, Mytilus californianus Conrad. J Invertebr Pathol 8: 109-121.

\section{BOOK REVIEW . . .}

Animal Agents and Vectors of Disease, by E. C. Faust, P. C. Beaver, and R. C. Jung. 4th Ed. Lea and Febiger, Philadelphia, 1975. ix +479 p. 201 text figures; 9 plates, 7 in color. $\$ 15.00$.

Beginning with the first edition in 1955, this text has been an excellent source of basic information on medical parasitology; this edition continues that tradition, with well-written chapters containing high-quality drawings and photographs, and many key references. The text has five sections: General Principles and Orientation (13 pages), Protozoan Agents of Human Disease (107 pages), Helminths as Agents of Human Disease (207 pages), Arthropods as Agents and Vectors (71 pages), and Technical Aids (41 pages).

The chapters on the protozoa in this edition, as compared to the third, include the recognition of Entamoeba hartmanni as a distinct species, which is nonpathogenic; new and updated sections on primary amebic meningoencephalitis, Isospora, Toxoplasma, Sarcocystis, Babesia, and Pneumocystis; and several new photographs of organisms and lesions.

The chapters on the helminths have been updated in terms of new information and references on epidemiology, pathogenesis, and treatment, and several new photographs of organisms and lesions have been added to this edition. The information on the arthropods and technical aids is virtually that of the third edition.

A general comment is that the recent findings on the immunological and pathophysiological aspects of parasitic infections received comparatively little emphasis, e.g., functional changes in
ZATKA, V. E., AND A. V. DolgIKH. 1963. A rare case of hyperparasitism of Haplosporidium of Urosporidium tauricum $\mathrm{sp}$. $\mathrm{n}$. in partenites of trematodes of the family Hemiuridae Lühe from the molluse Rissoa splendida Eichw. (In Russian, English summary.) Zool Zh 42: $1727-1729$.

the intestine associated with the enterics, immunodiagnosis of congenital toxoplasmosis. Specific comments to be considered by the authors in future editions follow. The term "cuticula" is used to identify the outer surface of flukes and cestodes as a secretion of the hypodermis; "integument" is the preferred term by several workers in view of ultrastructure studies that show the outer surface is distal cytoplasm of cells whose nucleated portion is located among parenchymal cells. The description of calcareous corpuscles leaves one with the impression that these are composed solely of calcium carbonate. Transmammary transmission of Toxocara canis and $T$. cati is omitted in comments on routes of infection in dogs and cats, respectively. The distribution stated for Loxosceles reclusus, i.e., Missouri and midwestern states, is more restricted than that reported by Butz (1971, Clin Toxicol 4: 515 ), who reports it as a major resident in the south central U. S., east from Texas to South Carolina, and south from Indiana to Alabamaexcluding Florida. The recently recognized and important role of mites in "house dust" allergy is not included; nor is adequate space given to the Hymenoptera in terms of allergic reactions. Rickettsiae are now generally considered as bacteria and hence should be included in that section. The micrometer has largely replaced the micron as a unit of length in most journals.

This edition will be a useful and comprehensive source of basic information on medical parasitology for medical students, and professionals in several of the biomedical disciplines.

Leroy J. Olson 